\title{
The Effect of Motivation, Leadership, and Job Satisfaction Toward Employee's Performance in the Directorate General of Immigration of the Central Office Jakarta
}

\author{
Gunartin $^{1}$, Ian Permana Wahyu ${ }^{2}$, Rahmi Hermawati ${ }^{3}$, Rima Handayani ${ }^{4}$ \\ Veta Lidya Delimah Pasaribu ${ }^{5}$, Denok Sunarsi ${ }^{6}$, Mahnun Mas'adi ${ }^{7}$, \\ Ali Maddinsyah ${ }^{8}$ \\ Department of Management, Faculty of Economic, Universitas Pamulang, Banten, \\ Indonesia \\ dosen01339@unpam.ac.id', dosen02023@unpam.ac.id², dosen00817@unpam.ac.id ${ }^{3}$, \\ dosen00551@unpam.ac.id ${ }^{4}$, dosen01889@unpam.ac.id ${ }^{5}$, denoksunarsi@unpam.ac.id ${ }^{6}$, \\ dosen01017@unpam.ac.id ${ }^{7}$, alimaddinsyah@unpam.ac.id ${ }^{8}$
}

\begin{abstract}
This study aims to determine the effect of motivation, leadership and job satisfaction on employee performance at the Directorate General of Immigration, Jakarta Central Office.The method used was explanatory research with a sample of 100 respondents. The Analysis technique uses statistical analysis with regression testing, correlation, determination and hypothesis testing. The Results of this study motivation significantly influence employee performance by $23.6 \%$, hypothesis testing obtained significance $0.000<0.05$. Leadership has a significant effect on employee performance by $35.6 \%$, hypothesis testing obtained significance $0.000<0.05$. Job satisfaction has a significant effect on employee performance by $22.2 \%$, hypothesis testing obtained significance $0.000<0.05$. Motivation, leadership and job satisfaction simultaneously have a significant effect on employee performance by $45.7 \%$, hypothesis testing obtained significance of $0.000<0.05$.
\end{abstract}

Keywords: Motivation, Leadership, Job Satisfaction, Employee Performance

\section{Introduction}

Reliable human resources will have a good performance as company assets. Human resources in developing competencies in overcoming internal and external problems of an established company must be developed. Consistent problem solving that is passed on to the next generation as the main capital in building an organizational culture so that new and old employees can feel and understand what is happening in the company. A company vision and mission that can be accepted well by employees can foster a sense of belonging and develop it.

The development of technology and the number of countries incorporated in THE ASEAN Economic Community (MEA/AEC) responds with their readiness in the face of the free market that one of them is the policy of service progress requires all agencies including public service sectors. The ability her service is a benchmark that is also important, in effect with THE ASEAN Economic Community (MEA/AEC) which has begun in the middle of february 2016 should be able to optimize supervision and monitoring of the existence of foreigners and the residence permit used, including by involving the relevant stake holders. 
In relation to immigration function, the integration of this area is very closely related to immigration management. In the future, every country is expected to be able to create a balance between the provision of easiness to people who perform crossing and improvement of supervision over the crossing of people within the area. Thus the complexity of the problem, as well as the impacts of economic, social and cultural, and the security posed. This movement will directly affect the development of the duties and functions of immigration that must be prepared by the reliable humanresources.

Each organization is required to compete, and is able to establish a strategy to strengthen the capacity of the Organization and human resources owned. Making changes to the organization and human Resources is one of the strategies to adapt to the environment, so that the organization can still survive and stabilize. The Directorate General of Immigration in accordance with law No. 6 Year 2011 is to carry out the function of Imigration(Keimigrasian) in the field of community service and protection, immigration law enforcement, and development facilitators. In the context of immigration service, it is necessary to improve public services that are transparent and accountable, for which it has been implemented by the bureaucracyreform.

According to Kurniawan and Holidin (2007), "The purpose of the grand design Bureaucracy Reform explicitly stated that it will create clean, integrity and other positive matters". In addition, it aims to create professional government bureaucracy with the characteristics of adaptive. It is undeniable that the success of an organization both overall and in groups is deeply influenced by the quality of leadership within the organization. Some research on the performance of bureaucracy reform in Indonesia gives the idea that most of the bureaucracy reform process has not succeeded. One interesting thing is that precisely most of the areas led by the reformers were able to demonstrate the existence of a good bureaucracy change (Ministry of Administrative reform of State, 2013). This suggests that good leadership will spur and encourage the spirit of the bureaucracy apparatus to perform well in accordance with the leadersdesired.

For it is necessary to change management in government bureaucracy. A leader, according to Wahjosumijo (2001), he states that "there are six traits that distinguish leaders with non leaders are: 1) spirit and ambition, 2) desire to lead and influence, 3) honesty and integrity, 4) confident, 5) smart, and 6) master the technical knowledge related to hisresponsibilities".

In addition, the factors that can influencing the success of the bureaucracy Reform Implementation are the motivation of employees to be better. According to VeithzalRivai (2013:837), he suggests "motivation is a series of attitudes and values that affect individuals to accomplish specific things according to individual objectives". Basically motivation can push ahead employees to achieve productivity or performance. The source of motivation itself are (1) the possibility to develop, (2) The type of work, (3) whether they can feel proud to be part of the company they work for. Motivation is also one of the factors that can support The achievement of maximum performance because according to Robbins (2006) that defines "Motivation as a process that participates in determining the intensity, direction, and persistence of individuals in the effort to reach the target".

The inconsistency of an organization can happen when the leaders pay less attention to the employee's potential and performance, resulting in a creativity assassination. This could lead to a latent rejection that caused the development of an "underground culture" that could affect organizational performance. In achieving its objectives, the Organization must be able to manage all the resources contained therein. One of the resource organizations that need attention and special arrangement is human resources. An organization must organize and facilitate the employee as good as possible in order to support their performance and create public 
accountability in the way to be a good governance.Each organization expect that their employees can perform well.

Information on employee performance is obtained through performance assessments. According to Handoko (2009) argues that "job satisfaction is essentially an individual thing, each individual has a different level of work satisfaction according to the wishes and value system he has adopted". When employees have a good level of satisfaction, they can improve their performance, and vice versa. In realizing its vision and mission, the Directorate General of Immigration of Central Office of Jakarta need to be supported by skilled and reliable human resources. When employees feel happy in their work, they generally have discipline and motivation. Conversely, if moral work or the spirit of their work is low, then they can adapt themselves to the bad habits. They may even not be polite toleaders.

The Pupose of Research:

a) In order to know the partial influence between the motivation to the performance of employees at the Directorate General of Immigration of the Central Office ofJakarta.

b) In order to know the partial influence between the leadership on the performance of employees at the Directorate General of Immigration of the Central Office ofJakarta.

c) In order to know the partial influence between job satisfaction ontheperformance of employees at the Directorate General of Immigration of the Central Office of Jakarta.

d) In order to know the simultaneous influence between motivation, leadership and job satisfaction on the performance of employees at the Directorate General of Immigration of the Central Office ofJakarta.

\section{Library Overview}

\subsection{Motivation}

According to Handoko (2009) that defines motivation as "the impulse that grows in a person, both from inside and outside himself to do a high-spirited work using all his abilities and skills that aim to get better work". In this study the indicators used include: intrinsic motivation (Internal) which includes: 1) The appropriation of a responsibility related to the assignment of work to be done, 2) Recognition of fulfillment the task, 3) The development of skills and career opportunities. Extrinsic motivation (external) which includes: 1) Intensive administration, 2) Comfortable working environment, 3) Safety in work, and 4) Good working relationship.

\subsection{Leadership}

According to Handoko (2009). He defines "Leadership is a behavior inherent in one's self is related to the influence of subordinates or the child in influencing activities about the way in which it works. In this research the indicators used include: a). Authority or granting of authority, B) Good communication, c) Motivation in fulfilling expectations and the avoidance form.

\subsection{Job Satisfaction}

According to Luthans (2006) defines "job satisfaction is the attitude of the attitudes that workers or employees have about their work resulting from their perception of work with the 
size of quality and quantity of work". In this research the indicators used include: a) The existence of appropriate salary, b) The existence of an opportunity to have a better position, c) The existence of supervision or oversight, d) Provision of appropriate allowances, e) Appreciation of an award in encouraging the spirit of employment, f) The rules or procedures of the prescribed work, g) A pleasant co-worker, h) The work itself, and i) There is good communication in the organization that bring through an optimal work progress.

\subsection{Employee Performance}

According to Hasibuan (2012) he defines "the work achieved by each employee in carrying out their duties and functions in the organization". In this research the indicators used include: a) The success of the work achievement achieved by the employee, b) Having the discipline in complying with the regulations in the Organization, c) Having the creativity in completing the work, d) Cooperate with other employees, E) Having the skills in bringing together the various elements of an organization or institution in drafting the wisdom, and f) have a responsibility to their work.

\section{Research Methods}

\subsection{Population}

The population 100 employees at the Directorate General of Immigration of the Central Office of Jakarta.

\subsection{Sample}

The sampling technique was carried out with saturated samples, the entire population of 100 employees was used as the research sample. All samples were given a questionnaire to answer responses to the questions given.

\subsection{Types of Research}

Associative research that identifies the relationship between the variables studied.

\subsection{Data Analysis Method}

Regression analysis based on the data that has been collected

\section{The Results of the Research}

\subsection{Descriptive Analysis}

The test is done by interpreting the data obtained by each score distribution. The results are as follows :

Table 1. Descriptive Statistics Analysis Results 


\section{Descriptive Statistics}

\begin{tabular}{cc|c|c|c|c}
\hline $\mathbf{N}$ & & Minimum & Maximum & Mean & Std. Deviation \\
\hline Leadership (X1) & 100 & 35 & 56 & 44.96 & 4.295 \\
\hline Leadership (X2) & 100 & 38 & 56 & 46.19 & 4.027 \\
\hline Job satisfaction (X3) & 100 & 36 & 56 & 46.10 & 4.350 \\
\hline Employees' performance (Y) & 100 & 39 & 56 & 47.04 & 4.030 \\
\hline N Valid (listwise) & 100 & & & & \\
\hline
\end{tabular}

\subsection{Verificative Analysis}

In this analysis, it is intended to find out the influence of independent variables toward the dependent variables. As for the following test results:

\section{a) Multiple Regression Analysis}

This regression test is intended to find out the change of a dependant variable if an independent variable changes. As for the results of the test as follows:

Table 2. The Result of Multiple Regression Test Coefficients $^{\mathrm{a}}$

\begin{tabular}{|c|c|c|c|c|c|c|}
\hline \multirow{2}{*}{\multicolumn{2}{|c|}{ Model }} & \multicolumn{2}{|c|}{$\begin{array}{c}\text { Unstandardized } \\
\text { Coefficients }\end{array}$} & \multirow{2}{*}{$\begin{array}{r}\begin{array}{c}\text { Standardized } \\
\text { Coefficients }\end{array} \\
\text { Beta }\end{array}$} & \multirow[b]{2}{*}{$\mathbf{t}$} & \multirow[b]{2}{*}{ Sig. } \\
\hline & & $\mathbf{B}$ & $\overline{\text { Std. Error }}$ & & & \\
\hline \multirow[t]{4}{*}{1} & (Constant) & 9.239 & 4.248 & & 2.175 & .032 \\
\hline & Leadership (X1) & .249 & .078 & .265 & 3.188 & .002 \\
\hline & Leadership (X2) & .402 & .089 & .401 & 4.491 & .000 \\
\hline & Job Satisfaction (X3) & .175 & .081 & .189 & 2.163 & .033 \\
\hline
\end{tabular}

a.Dependent Variable: Employee performance(Y)

Based on the result of the test at table above, it is obtained the regression equation of $\mathrm{Y}=$ $9.239+0.249 \times 1+0.402 \times 2+0.175 \times 3$. From this equation described asfollows:

a) A 9.239 constant is meant that motivation and leadership do not exist. Thus, there is a value of employees' performance of 9.239points.

b) The motivation regression coefficient of 0.249 indicates a prediction of the effect of increasing motivation by 0.249 which will provide an increase in employee performance.

c) The leadership regression coefficient of 0.402 predicts the effect of increasing the performance of the same employees.

d) Job satisfaction regression by 0.175 , employees'performance

b) Correlation Coefficient Analysis

Correlation coefficcient analysisgiven in Table 3.

Table 3. The Result of Motivational Correlation Coefficcient Test toward Employees' performance Correlations $^{b}$

\begin{tabular}{llrr}
\hline & & $\begin{array}{c}\text { Motivation } \\
\text { (X1) }\end{array}$ & $\begin{array}{c}\text { Employees' } \\
\text { Performance (Y) }\end{array}$ \\
\hline Motivation (X1) & Pearson Correlation & 1 & $.486^{* *}$ \\
& Sig. (2-tailed) & & .000 \\
& Pearson Correlation & $.486^{* *}$ & 1 \\
\hline
\end{tabular}




$\begin{aligned} & \text { Employees' performance } \quad \text { Sig. (2-tailed) } \\ & \text { (Y) }\end{aligned}$
**. Correlation is significant at the 0.01 level(2-tailed).
b. Listwise $\mathrm{N}=100$

Table 4. The Result of Leadership Correlation Coefficient Test toward Employees' Performance Correlations $^{\mathbf{b}}$

\begin{tabular}{llr|r}
\hline & & Leadership (X2) & \multicolumn{1}{c}{$\begin{array}{c}\text { Employees' } \\
\text { Performance (Y) }\end{array}$} \\
\hline \multirow{2}{*}{ Leadership (X2) } & Pearson Correlation & 1 & $.596^{* *}$ \\
\cline { 2 - 4 } & Sig. (2-tailed) & .000 \\
\hline \multirow{2}{*}{$\begin{array}{l}\text { Employees' Performance } \\
\text { (Y) }\end{array}$} & Pearson Correlation & $.596^{* *}$ & 1 \\
\cline { 2 - 4 } & Sig. (2-tailed) & .000 & \\
\hline$* *$ Correlation is significant at the 0.01 level(2-tailed) & &
\end{tabular}

**. Correlation is significant at the 0.01 level(2-tailed).

b. Listwise $\mathrm{N}=100$

Based on the results of the test, a correlation value of 0.596 means that leadership has a moderate relation toward employees' performance.

Table 5. The Result of Job Satisfaction Correlation Coefficient Test toward Employees' Performance Correlations $^{\text {b }}$

\begin{tabular}{|c|c|c|c|}
\hline & & $\begin{array}{c}\text { Job Satisfaction } \\
(\mathrm{X} 3)\end{array}$ & $\begin{array}{c}\text { Employees' } \\
\text { Performance (Y) } \\
\end{array}$ \\
\hline \multirow{2}{*}{ Job Satisfaction (X3) } & Pearson Correlation & 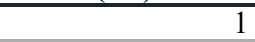 & $.471^{* *}$ \\
\hline & Sig. (2-tailed) & & .000 \\
\hline \multirow{2}{*}{$\begin{array}{l}\text { Employees' Performance } \\
\text { (Y) }\end{array}$} & Pearson Correlation & $.471^{* *}$ & 1 \\
\hline & Sig. (2-tailed) & .000 & \\
\hline
\end{tabular}

**. Correlation is significant at the 0.01 level(2-tailed).

b. Listwise $\mathrm{N}=100$

Table 6. The Result of Correlation Coefficient Test of Motivation, Job Satisfaction, and Leadership Simultaneously toward Employees' Performance

Model Summary

\begin{tabular}{cc|c|c|c}
\hline Model & $\mathbf{R}$ & R Square & $\begin{array}{c}\text { Adjusted R } \\
\text { Square }\end{array}$ & $\begin{array}{c}\text { Std. Error of the } \\
\text { Estimate }\end{array}$ \\
\hline 1 & $.676^{\mathrm{a}}$ & .457 & .440 & 3.015 \\
\hline
\end{tabular}

a. Predictors: (Constant), Job Satisfaction (X3), Motivation (X1), Leadership (X2)

\section{c) Determination Coefficient Analysis}

Coefficient analysis of the determination given in Table7.

Table 7. The Result of Motivational Determination Coefficient Test toward Employees' Performance Model Summary

\begin{tabular}{cc|r|rrr}
\hline Model & R & R Square & $\begin{array}{c}\text { Adjusted R } \\
\text { Square }\end{array}$ & $\begin{array}{c}\text { Std. Error of the } \\
\text { Estimate }\end{array}$ \\
\hline 1 & $.486^{\mathrm{a}}$ & .236 & .229 & 3.539 \\
\hline
\end{tabular}

a. Predictors: (Constant), Motivation(X1)

Based on the result of the test, a determination value of 0.236 means that motivation has an influence contribution of $23.6 \%$ toward employees' performance. 
Table 8. The Result of Leadership Determination Coefficient Test toward Employees' Performance Model Summary

\begin{tabular}{ccrrr}
\hline Model & R & R Square & $\begin{array}{c}\text { Adjusted R } \\
\text { Square }\end{array}$ & $\begin{array}{c}\text { Std. Error of the } \\
\text { Estimate }\end{array}$ \\
\hline 1 & $.596^{\mathrm{a}}$ & .356 & & .349 \\
\hline a. Predictors: (Constant), Leadership (X2) & & & &
\end{tabular}

Based on the result of the test, a determination value of 0.356 means that leadership has an influence contribution of $35.6 \%$ toward employees' performance

Table 9. The Result of Job Satisfaction Determination Coefficient Test toward Employees' Performance Model Summary

\begin{tabular}{crr|r|r|r}
\hline Model & R & \multicolumn{2}{c}{ R Square } & $\begin{array}{c}\text { Adjusted R } \\
\text { Square }\end{array}$ & $\begin{array}{c}\text { Std. Error of the } \\
\text { Estimate }\end{array}$ \\
\hline 1 & & $.471^{\mathrm{a}}$ & .222 & .214 & 3.573 \\
\hline
\end{tabular}

a. Predictors: (Constant), Job Satisfaction (X3)

Table 10. The Result of Determination Coefficient of Motivation, Leadership, and Job Satisfaction toward Employees' Performance

Model Summary

\begin{tabular}{cr|r|rrr}
\hline Model & R & \multicolumn{2}{|c|}{ R Square } & $\begin{array}{c}\text { Adjusted R } \\
\text { Square }\end{array}$ & $\begin{array}{c}\text { Std. Error of the } \\
\text { Estimate }\end{array}$ \\
\hline 1 & $.676^{\mathrm{a}}$ & .457 & .440 & 3.015 \\
\hline
\end{tabular}

a. Predictors: (Constant), Job Satisfaction (X3), Motivation (X1), Leadership (X2)

Based on the test results obtained determination of 0.457 , the contribution of motivation, leadership, and job satisfaction is $45.7 \%$ simultaneously to employee performance, while the remaining $54.3 \%$ is influenced by other factors.

\subsection{Hypothetical Testing}

\section{a) t Test}

Hypothesis testing with $\mathrm{t}$ test is used to find out which partial hypotheses are accepted.

Table 11. The Result of Motivational Hypothesis toward Employee's Performance Coefficients $^{\text {a }}$

\begin{tabular}{|c|c|c|c|c|c|c|}
\hline \multirow[b]{2}{*}{ Model } & & \multicolumn{2}{|c|}{$\begin{array}{l}\text { Unstandardized } \\
\text { Coefficients }\end{array}$} & \multirow{2}{*}{$\begin{array}{c}\begin{array}{c}\text { Standardized } \\
\text { Coefficients } \\
\text { Beta }\end{array} \\
\end{array}$} & \multirow[b]{2}{*}{$\mathbf{t}$} & \multirow[b]{2}{*}{ Sig. } \\
\hline & & B & Std. Error & & & \\
\hline \multirow{2}{*}{1} & (Constant) & 26.524 & 3.741 & & 7.090 & .000 \\
\hline & Motivation (X1) & .456 & .083 & .486 & 5.509 & .000 \\
\hline
\end{tabular}

a. Dependent Variable: Employee Performance(Y)

Table 12. The Result of Leadership Hypothesis toward Employees' Performance Coefficients $^{\mathrm{a}}$

\begin{tabular}{lcc|c|c|c}
\hline & \multicolumn{2}{c}{$\begin{array}{c}\text { Unstandardized } \\
\text { Coefficients } \\
\text { Model }\end{array}$} & $\begin{array}{c}\text { Standardized } \\
\text { Coefficients } \\
\text { Beta }\end{array}$ & t & Sig. \\
\hline
\end{tabular}




\begin{tabular}{rlr|r|r|r|r}
\hline \multirow{2}{*}{1} & (Constant) & 19.470 & 3.762 & & 5.175 & .000 \\
\cline { 2 - 7 } & Motivation (X1) & .597 & .081 & .596 & 7.356 & .000 \\
\hline
\end{tabular}

a. Dependent Variable: Employee Performance (Y)

Table 13. The Result of Job Satisfactional Hypothesis toward Employees' Performance Coefficients $^{\mathrm{a}}$

\begin{tabular}{|c|c|c|c|c|c|c|}
\hline \multirow[b]{2}{*}{ Model } & & \multicolumn{2}{|c|}{$\begin{array}{l}\text { Unstandardized } \\
\text { Coefficients }\end{array}$} & \multirow{2}{*}{$\begin{array}{l}\text { Standardized } \\
\text { Coefficients } \\
\text { Beta }\end{array}$} & \multirow[b]{2}{*}{$\mathbf{t}$} & \multirow[b]{2}{*}{ Sig. } \\
\hline & & B & Std. Error & & & \\
\hline & (Constant) & 26.916 & 3.822 & & 7.042 & .000 \\
\hline & Job Satisfaction (X3) & .437 & .083 & .471 & 5.288 & .000 \\
\hline
\end{tabular}

a. Dependent Variable: Employee Performance(Y)

Based on the test results at the table above, it is obtained that the value of $t$ count $>t$ table or $(5.288>1.984)$, thus the third hypothesis proposed has a significant influence between job satisfaction and employees' performance isaccepted.

\section{b) Simultaneous Hypothetical Test (F Test)}

Hypothetical testing with the F test in table 14.

Table 14. The Result of Motivation, Leadership, and Job Satisfaction Hypothesis toward Employees'

\begin{tabular}{rlr|r|r|r|r}
\multicolumn{7}{c}{$\begin{array}{c}\text { Performance } \\
\text { ANOVA }^{\mathbf{a}}\end{array}$} \\
\hline \multirow{2}{*}{ Model } & & \multicolumn{1}{c}{$\begin{array}{c}\text { Sum of } \\
\text { Squares }\end{array}$} & df & Mean Square & \multicolumn{1}{c}{ F } & Sig. \\
\hline \multirow{3}{*}{1} & Regression & 735.160 & 3 & 245.053 & 26.957 & $.000^{\mathrm{b}}$ \\
\cline { 2 - 8 } & Residual & 872.680 & 96 & 9.090 & & \\
\cline { 2 - 8 } & Total & 1607.840 & 99 & & & \\
\hline
\end{tabular}

a. Dependent Variable: Employee Performance(Y)

b. Predictors: (Constant), Job Satisfaction (X3), Motivation (X1), Leadership(X2)

\subsection{Study Results}

\section{a) The Influence of Motivation toward Employee's Performance}

The correlation value is 0.489 between motivation and employee performance. Based on the hypothesis testing, the $\mathrm{t}$-count value is $4.4 \mathrm{t}$ table or $(5.509>1.984)$. motivation as a benchmark in building self-confidence and enthusiasm for work, when employee motivation is good it will greatly determine their performance, with good enthusiasm, attention and confidence.

\section{b) The Influence of Leadership toward Employee's Performance}

The correlation of 0.596 for leadership, Responsible, fair and wise leadership management will determine the performance of its employees' performance.

\section{c) The Influence of Job Satisfaction toward Employee's Performance}

Job satisfaction has a significant influence toward employee's performance with a correlation 
value of 0.471 or has a strong relation with influence contribution of $22.2 \%$. Hypothetical testing the value of $(5.288>1.984)$. Thus the third hypothesis proposed has a significant influence between job satisfaction and employee's performance is accepted.

\section{d) The Influence of Motivation, Leadership, and Job Satisfaction toward Employee's Performance}

Motivation and leadership have significant influence toward employee's performance which are obtained the regression equation of $\mathrm{Y}=9.239+0.249 \mathrm{X} 1+0.402 \mathrm{X} 2+0.175 \mathrm{X} 3$, meaning that there is a simultaneous influence between variables.

\section{Conclusions and Suggestions}

\subsection{Conclusions}

a) Contribution of the influence of motivation $23.6 \%$ to employee performance $(5,509>1,984)$. Motivation has an important role in improving employee performance, motivation for a good work in humans which can be said to be external and internal.

b) the influence of the influence of $35.6 \%$ of leadership on employee performance with $(7,356>$ 1,984 ) that responsible, fair and wise leadership and good management, the employee performance will be better

c) Job satisfaction effect on employee performance with impact contribution of 22.2\% (5.288> 1.984).

d) The contribution of $45.7 \%$ with motivation, leadership, and job satisfaction that have a significant effect, the remaining $54.3 \%$ by other factors based on the $\mathrm{F}$ value $>\mathrm{F}$ table or $(26,957>2,700)$.

\subsection{Suggestions}

a) The institution should always provide encouragement and proper appreciation to ensure that employees have a high spirit atworking.

b) The leader must be able to implement democratic leadership patterns so that employees can implement policiesproperly.

c) Employees must have high dedication and strive to be able to implement all of the organization's policiesproperly.

d) Employees' performance can be more enhanced by empowering employees by enforcing good regulations and providing work instruction that workers are able toapply.

\section{References}

[1] Arikunto, Suharsimi (2014). "A Research Procedure of A Practice Approach".Jakarta: RinekaCipta.

[2] D Sunarsi. (2017). The Influence of Organizational Leadership and Culture toward Employee's Performance at Branch DKI Banker, PondokLabu- South Jakarta. GENIUS 1 (2),21 Gumilar, I., Sunarsi, D. (2020). Comparison of financial performance in banking with high car and low car 
(Study of banks approved in the kompas 100 index for the period 2013-2017).International Journal of Psychosocial Rehabilitation. Volume 24 - Issue 7

[3] Erlangga, H. (2020). The Challenges of Organizational Communication in the Digital Era. Solid State Technology, 63(4), 1240-1246.

[4] Erlangga, H., Sifatu, . W. O., Wibisono, . D., Siagian, . A. O., Salam, . R., Mas'adi, . M., Gunartin, ., Oktarini, . R., Manik, . C. D., Nani, ., Nurhadi, . A., Sunarsi, . D., Purwanto, . A. \& Kusjono, . G. (2020) Pharmaceutical Business Competition in Indonesia: A Review. Systematic Reviews in Pharmacy, 11 (10), 617-623. doi:10.31838/srp.2020.10.92

[5] Gumilar, I., Sunarsi, D. (2020). Comparison of financial performance in banking with high car and low car (Study of banks approved in the kompas 100 index for the period 2013-2017). International Journal of Psychosocial Rehabilitation. Volume 24 - Issue 7

[6] Gunartin, Siagian, . A. O., Nufus, . K., Yusuf, . N., Supratikta, . H., Maddinsyah, . A., Muchtar, . A., Sari, . W. I., Sunarsi, . D., Akbar, . I. R., Arianto, . N., Purwanto, . A., Noryani, . \& Wijoyo, . H. (2020) A Systematic Literature Review of Education Financing Model in Indonesian School. Systematic Reviews in Pharmacy, 11 (10), 638-644. doi:10.31838/srp.2020.10.96

[7] Hasibuan, SP, "Banking Basics" Haji Masagung, Jakarta, 2012.

[8] Hidayat, D., Prabowo, B., \& Anwar, S. (2020). Organizational Leadership and Conflict in Human Resource Management Review. Solid State Technology, 63(6), 1372-1381.

[9] Imam Ghozali (2017). "Multivariate analysis applications with SPSSprogram". Fifth Edition. Semarang: Agency Publisher of Undip.

[10] Kembara, M.D, Hanny, R., Gantina, N., Kusumawati, I., Budimansyah, D., Sunarsi, D., Khoiri, A. (2020). Scientific Literacy Profile Of Student Teachers On Science For All Context. Solid State Technology. Vol. 63 No. 6

[11] Lukiastuti, Fitri, et.al (2020). The Influence of Entrepreneur's Personal Characteristics on SMES Performance Mediated by Entrepreneurial Orientation. International Journal of Psychosocial Rehabilitation. Volume 24 - Issue 8

[12] Maddinsyah, A., Sunarsi, D., Hermawati, R., Pranoto. (2020). Analysis of location selection effect on the user decision that influcence the success of the service business of micro, small and medium enterprise (MSME) in bandung timur region. International Journal of Advanced Science and Technology. Vol. 29 No. 06

[13] Nufus, K., Supratikta, H., Muchtar, A., Sunarsi, D. (2020). Analysis of Financial Performance: Case Study of PT. X Employee Cooperative. Utopía Y Praxis Latinoamericana. Año: 25, $\mathrm{N}^{\circ}$ Extra 10, 2020, pp. 429-444

[14] PAN Minister Regulation and RB number : 20 year 2010 about Bureaucratic reform Roadmap

[15] Purwanto, H., Fauzi, . M., Wijayanti, . R., Awwaly, . K. U. A., Jayanto, . I., Mahyuddin, ., Purwanto, . A., Fahlevi, . M., Adinugraha, H. H., Syamsudin, . R. A., Pratama, . A., Ariyanto, . N., Sunarsi, . D., Hartuti, . E. T. K. \& Jasmani, . (2020) Developing Model of Halal Food Purchase Intention among Indonesian Non-Muslim Consumers: An Explanatory Sequential Mixed Methods Research. Systematic Reviews in Pharmacy, 11 (10), 396-407. doi: $10.31838 /$ srp.2020.10.63

[16] Santoso, Singgih (2015). "Mastering Multivariate Statistics". Jakarta: Elex Media Komputindo Corp.

[17] Sobarna, A., Rizal, R. M., Hambali, S., \& Sunarsi, D. (2020). Influence Make a Match Model toward Communication skills in Physical and Health Pedagogical Concept. Solid State Technology, 63(6), 1355-1363.

[18] Sobarna, A., Sunarsi, D., \& Roinadi, D. K. (2020). The Effect of Pedagogic Competence Kids Athletic toward Motivation for Elementary School. Solid State Technology, 63(6), 1364-1371.

[19] Sugiyono (2017), "Administrative Research Methods: Complemented by R\&D Method". Bandung: Alfabeta.

[20] Sunarsi, D. (2019). Human Resource Colloquy. South-East Tangerang :Unpam Press.

[21] Sunarsi, D. (2019). The Analysis of The Work Environmental and Organizational Cultural Impact on The Performance and Implication of The Work Satisfaction. 
JurnalIlmiahIlmuAdministrasiPublik, 9(2), 113-122.: Alfabeta

[22] Sunarsi, D. (2020). The Influence of Supply Chain Strategy on Employee Performance on Small and Medium Business in Beringharjo Market, Yogyakarta- Indonesia. International Journal of Supply Chain Management. Vol. 9, No. 5

[23] Sunarsi, D., Rohaeni, . N., Wulansari, . R., Andriani, . J., Muslimat, . A., Rialmi, . Z., Kustini, . E., Kristianti, . L. S., Rostikawati, . D., Effendy, . A. A., Purwanto, . A. \& Fahlevi, . M. (2020) Effect of e-Leadership Style, Organizational Commitment and Service Quality towards Indonesian School Performance. Systematic Reviews in Pharmacy, 11 (10), 472-481. doi:10.31838/srp.2020.10.71

[24] Supriyadi, D., Syafitri, . L. N. H., Widodo, S. F. A., Wahidi, R., Arinta, . Y. N., Nabhan, . F., Mufid, . A., Purwanto, . A., Fahlevi, . M., Sunarsi, . D. \& Cahyono, . Y. (2020) Innovation And Authentic Leadership Of Islamic University Lectures In Faculty Pharmacy Faculty: What Is The Role Of Psychological Capital?. Systematic Reviews in Pharmacy, 11 (8), 383-393. doi:10.31838/srp.2020.8.56

[25] Suryani, N. L., Sularmi, L., Eka, P. D., Sunarsi, D., \& Maddinsyah, A. (2020). The Analysis of Career Development and Placement of Employee Performance in Pt. Global Means of Transindo in Jakarta. Solid State Technology, 63(6), 1382-1389.

[26] Syobar, K., Hardiyan, A., Romlah, O. Y., Yusup, M., \& Sunarsi, D. (2020). The Effect of Service Quality and Price on Purchase Decisions in Woodpecker Coffee in South Jakarta. Solid State Technology, 63(6), 1491-1504. 